\title{
PENERAPAN PSAK NO. 45 DALAM PELAPORAN KEUANGAN PANTI ASUHAN YAYASAN ISLAM MEDIA KASIH TAHUN 2017
}

\author{
Wiladatika $^{1}$, Yossi Diantimala ${ }^{* 2}$ \\ 1,2 Program Studi Akuntansi Fakultas Ekonomi Universitas Syiah Kuala \\ e-mail: wiladatika@mhs.unsyiah.ac.id 1, ydiantimala@unsyiah.ac.id *2

\section{* Corresponding Author}

\begin{abstract}
There are lots of non-profit organization needs transparency and accountability in financial reports to engage donors to donate in Indonesia today. To support them, Ikatan Akuntan Indonesia has produced PSAK No. 45 about non-profit organization financial reports. This research placed in Yayasan Islam Media Kasih orphanage that has been one of non-profit organizations. The aim of this research is to identify whether the orphanage has applied PSAK No. 45 in their financial reports. Descripive research methods with qualitative analysis techniques outlines, describe and compare the data. The results showed they not match with the arranging of financial reports based on PSAK No. 45 formats. There are just revenue reports, expense reports, and balance sheets based form their own understanding. The Orphanage does not provide yet the reports o financial position, activity reports, cash flow reports, and the record of financial reports. Preferably, the orphanage provides the financial reports based on PSAK No. 45 to be more transparent and accountable so as to engage the donors
\end{abstract}

Keywords: Accountability, Financial Reports, Non-profit Organizations, PSAK No. 45, Transparancy

\section{Pendahuluan}

Pernyataan Standar Akuntansi Keuangan (PSAK) adalah kumpulan dari standar yang digunakan dalam praktik akuntansi di Indonesia, yang mana disusun dan diterbitkan oleh Ikatan Akuntan Indonesia (IAI). Sedangkan Pernyataan Standar Akuntansi (PSAK) No. 45 adalah pedoman dalam menyusun laporan keuangan pada entitas nirlaba. PSAK No. 45 ini dikeluarkan pada tanggal 23 Desember 1997 dan revisinya disahkan pada tanggal 8 April 2011 oleh Dewan Standar Akuntansi.

Entitas nirlaba atau organisasi nonprofit adalah suatu organisasi yang orientasi kegiatannya berpusat pada perihal dalam menarik perhatian publik dengan tujuan yang tidak komersil, tanpa perhatian terhadap hal-hal yang bersifat mencari laba (moneter) (Ardana: 2012). Entitas nirlaba ini bisa dimiliki oleh pemerintah maupun pihak swasta dengan tujuan untuk kepentingan masyarakat banyak. Entitas nirlaba meliputi rumah ibadah, sekolah, yayasan, panti sosial, derma publik, rumah sakit, organisasi politis, bantuan masyarakat dalam perundang-undangan, serikat buruh, asosiasi profesional, museum, dan lain-lain.
Menurut Kepmensos No.50/HUK/2004 panti sosial adalah lembaga pelayanan kesejahteraan sosial ke arah kehidupan normatif secara fisik, mental, dan sosial. Panti sosial merupakan salah satu contoh entitas nirlaba yang banyak terdapat di sekitar kita seperti panti asuhan, panti jompo, dan lainnya. Panti asuhan atau panti sosial asuhan anak juga Lembaga Kesejahteraan Anak (LKSA) adalah lembaga sosial nirlaba yang menerima, menampung, mendidik, dan memelihara anak-anak yatim, piatu, yatim piatu, serta anak terlantar.

Berdasarkan pernyataan Kementrian Sosial Republik Indonesia, terdapat 3,5 juta anak terlantar di Indonesia yang diasuh di panti asuhan. Diantaranya terdapat 1.615 LKSA terakreditasi dan 5.824 LKSA mendapat bantuan permakanan, tetapi belum diakreditasi. dari data tersebut, sebanyak sembilan panti asuhan milik pemerintah pusat, 88 panti asuhan yang dimiliki pemerintah daerah, dan 5.727 panti yang dikelola oleh masyarakat. Tujuan dari dilakukannya akreditasi adalah agar panti asuhan dapat dievaluasi kinerjanya dan kehidupan anak-anak terjamin dari tindak kekerasan, penyalahgunaan nama panti, perdagangan anak, dan lain-lain yang dapat 
mengancam keselamatan para anak. (Harian Nasional, 2018).

Menurut Surya.co.id (2009) melaporkan bahwa sebanyak 20 kiai pengelola yayasan panti asuhan di Pamekasan, Madura, Jawa Timur, terindikasi terlibat kasus korupsi dana bantuan yayasan panti asuhan yang dikelolanya. Hal ini disebabkan dana bantuan yang harusnya dialokasikan untuk konsumsi, malah dialokasikan untuk pembangunan, kelengkapan sarana dan prasarana, dan kebutuhan lainnya. Hal ini tentu keliru, karena tidak adanya akuntabilitas dalam mengelola dana bantuan yang telah diberikan, sehingga mereka ditetapkan sebagai tersangka.

Contoh kasus penyelewengan dana Panti Asuhan Samuel di Kelapa Dua, Kabupaten Tangerang juga dapat dijadikan referensi. Dimana para donator memberikan bantuan secara rutin, tapi anak-anak panti tidak mendapatkan perlakuan yang layak. Bahkan mereka juga mendapat perlakuan tindak kekerasan yang menyebabkan kaburnya anak-anak panti. Hal ini dikarenakan tidak adanya transparansi dan akuntabilitas dalam laporan keuangan panti asuhan yang sesuai dengan PSAK No.45. (Detik News, 2014).

Selain kasus di atas, terdapat pula kasus dugaan penggelapan dana anak panti yang terjadi di Panti Asuhan Taman Harapan Langsa, Aceh. Forum Peduli Rakyat Miskin (FPRM) meminta polisi untuk mengusut dugaan korupsi tersebut setelah mendapat laporan dari anak panti bahwa mereka diharuskan menandatangi kwitansi, tetapi tidak mendapatkan uang saku. Saat dikonfirmasi, pengurus panti mengatakan bahwa sedang menunggu amprahan cair dari Dinas Sosial. Namun, karena kurangnya transparansi, maka terjadilah pelaporan ke pihak polisi. (Serambinews.com, 2014).

Penelitian ini memiliki tujuan untuk mengetahui peneparan PSAK No. 45 pada pelaporan keuangan Panti Asuhan Yayasan Islam Media Kasih beserta alasannya jika belum sesuai. Selain itu juga untuk melihat proses penyusunan laporan keuangannya serta perbedaan laporan pasti tersebut dengan PSAK No. 45.

\section{Kerangka Teoritis Dan Pengembangan Hipotesis \\ Pengertian Organisasi Nirlaba}

Organisasi adalah sistem peran, diagram aktivitas dan proses (pola hubungan kerja) yang melibatkan beberapa orang sebagai pelaksana tugas yang dirancang untuk mencapai tujuan bersama (Torang, 2013). Organisasi nirlaba atau organisasi nonprofit tidak sama dengan organisasi bisnis yang berpusat pada laba atau keuntungan, tetapi organisasi ini lebih memusatkan pada kepentingan sosial dan tidak bertujuan untuk menghasilkan laba.

\section{Karakteristik Organisasi Nirlaba}

Karakteristik organisasi nirlaba berbeda dengan organisasi bisnis. Perbedaan utama yang mendasar terletak pada cara organisasi nirlaba memperoleh sumber daya yang dibutuhkan untuk melakukan aktivitas-aktivitas operasinya. Organisasi nirlaba memperoleh sumber pendanaan dari sumbangan para anggota dan para penyumbang lainnya yang tidak mengharapkan imbalan dalam bentuk apapun dari organisasi tersebut (Hendrawan, 2011).

\section{Pengertian Yayasan}

Menurut Purba (2015:43) yayasan adalah "badan hukum yang terdiri dari kekayaan yang dipisahkan dan diperuntukkan untuk mencapai tujuan tertentu di bidang sosial, keagamaan, dan kemanusiaan yang tidak mempunyai anggota". Contohnya di bidang sosial yang paling umum antara lain panti asuhan, panti jompo, dan bidang pendidikan. Lalu di bidang keagamaan, diantaranya pendidikan agama, media dan lain-lain. Selanjutnya di bidang kemanusiaan contohnya penanggulangan bencana. Segala hal mengenai yayasan telah diatur dalam UU No. 16 Tahun 2001 tentang Yayasan dan UU No. 28 Tahun 2004 tentang Perubahan Terhadap UU No. 16 Tahun 2001 tentang Yayasan.

\section{Jenis-Jenis Pendapatan Yayasan (Sumbangan)}

Pendapatan yang diperoleh dibagi dalam beberapa kategori berdasarkan restiksi (pendapatan) yang ditentukan oleh asal pendapatan itu. Menurut Bastian (2007:74) pendapatan yayasan dibagi dalam kategori sebagai berikut:

\section{a. Pembatasan Permanen}

Sumbangan atau donasi ini telah memiliki pembatasan penggunaan yang jelas dari penyumbangnya agar dapat dipertahankan secara permanen. Yayasan mendapat izin untuk 
memakai sebagian atau seluruh penghasilan atau manfaat ekonomi lainnya yang bersumber dari sumbangan tersebut.

b. Pembatasan Temporer

Sumbangan atau donasi ini diperoleh secara khusus dan penyumbangnya menyebutkan tujuan pemanfaatan sumbangannya serta batas periode penggunaanya.

c. Sumbangan Terikat

Pendapatan ini telah dibatasi hanya untuk tujuan tertentu, dapat bersifat permanen maupun temporer.

d. Sumbangan Tidak Terikat

Pihak pendonor tidak membatasi tujuan pemanfaatan sumbangan tersebut, sehingga pihak yayasan bebas menggunakannya.

\section{Pengertian Panti Asuhan}

Kamus Besar Bahasa Indonesia telah mendefinisikan panti asuhan sebagai rumah tempat mnemelihara dan merawat anak yatim atau yatim piatu dan sebagainya. Kesimpulan yang dapat diambil dari penjelasan di atas adalah panti asuhan adalah lembaga usaha dibidang kesejahteraan sosial yang bertanggung jawab dalam memberikan beberapa pelayanan, terutama pelayanan pengganti dalam pemenuhan kebutuhan fisik, mental, dan sosial pada anak-anak asuhnya, sehingga nantinya para anak asuh akan memperoleh kesempatan yang luas, tepat, dan memadai bagi kepribadiannya sesuai dengan yang diharapkan agar menjadi generasi penerus bangsa.

\section{Tujuan Panti Asuhan}

Para pemilik panti mungkin memiliki tujuan tersendiri pada anak-anak asuhnya, namun sebenarnya pemerintah telah mengatur tujuan panti asuhan seperti yang tertuang dalam keterangan yang diatur oleh Departemen Sosial Republik Indonesia ini:

a. Panti asuhan memberikan pelayanan yang berdasarkan pada profesi sosial kepada anak terlantar dengan cara membantu dan membimbing mereka kearah perkembangan pribadi yang wajar serta mempunyai keterampilan kerja, sehingga mereka menjadi anggota masyarakat yang dapat hidup layak dan penuh tanggung jawab, baik terhadap dirinya, keluarga, dan masyarakat.

b. Tujuan penyelenggaraan pelayanan kesejahteraan sosial anak di panti asuhan adalah terbentuknya manusia-manusia yang berkepribadian matang dan berdedikasi, mempunyai keterampilan kerja yang mampu menopang hidupnya dan hidup keluarganya.

Dari uraian di atas dapat kita simpulkan bahwa sebenarnya pemerintah dan masyarakat yang bergerak dalam bidang sosial, khususnya panti asuhan ini, memiliki tujuan yang sama, yaitu memberikan pelayanan, bimbingan, dan keterampilan serta membentuk karakter mereka agar dapat menjadi manusia yang sesuai harapan negara dan dapat bersaing dalam hal meraih cita-cita mereka nantinya.

\section{Fungsi Panti Asuhan}

Menurut Departemen Sosial Republik Indonesia, panti asuhan mempunyai fungsi sebagai berikut:

a. Sebagai pusat pelayanan kesejahteraan sosial anak.

b. Sebagai pusat data dan informasi serta konsultasi kesejahteraan sosial anak.

c. Sebagai pusat pengembangan keterampilan (yang merupakan fungsi penunjang).

Berdasarkan penjelasan di atas, dapat kita simpulkan bahwa fungsi dari panti asuhan ialah untuk memberikan pelayanan, informasi, konsultasi, dan pengembangan keterampilan bagi kesejahteraan sosial anak.

\section{Pengertian Laporan Keuangan}

Laporan keuangan (financial statements) adalah dokumen bisnis yang digunakan perusahaan untuk melaporkan hasil aktivitasnya kepada berbagai kelompok pemakai, meliputi manajer, investor, kreditor, dan agen regulator. Sebaliknya, pihak-pihak tersebut menggunakan informasi yang dilaporkan untuk menentukan kebijakan, seperti apakah akan berinvestasi atau meminjamkan uang kepada perusahaan (Walter T, 2011:2). Segala sesuatunya pasti memiliki tujuan dan begitu juga dengan laporan keuangan. Tujuan laporan keuangan adalah menyediakan informasi yang berkaitan dengan posisi keuangan, kinerja serta perubahan posisi keuangan suatu entitas yang berguna untuk sejumlah besar pengguna dalam proses pengambilan keputusan ekonomi (Pontoh, 2013). 


\section{Unsur-Unsur Laporan Keuangan}

SFAC No. 6 menyatakan sepuluh unsur laporan keuangan. Unsur-unsur tersebut antara lain aktiva, kewajiban, ekuitas, investasi oleh pemilik, distribusi kepada pemilik, laba komprehensif, pendapatan, beban, keuntungan, dan kerugian (Hery, 2013: 35).

\section{Kualitas Informasi Laporan Keuangan}

Mamesah (2013) menyatakan bahwa "laporan keuangan pada dasarnya harus memiliki kualitas informasi atau karakteristik kualitatif agar dapat memberikan informasi yang berkualitas tinggi bagi para pemakainya seperti dapat dipahami, relevan, keandalan, dan dapat dibandingkan". Unsur-unsur tersebut haruslah ada agar dapat laporan keuangan tersebut berkualitas tinggi.

\section{Pengakuan, Pengukuran, dan Pelaporan}

Pengakuan (recognition) adalah proses pencatatan item-item dalam ayat jurnal, dimana untuk setiap item yang diakui harus memenuhi salah satu definisi dari unsur laporan keuangan (Hery, 2013). Selanjutnya, Hery (2013:38) menyatakan bahwa "mengenai kriteria pengukuran, saat ini ada 5 atribut pengukuran yang digunakan dalam praktek akuntansi yaitu biaya historis (historical cost), biaya pengganti (current replacement cost), nilai pasar (current market value), nilai bersih yang dapat direalisasi (net realizable value), dan nilai sekarang atau nilai yang di-diskontokan (present/discounted value)".

\section{Pelaporan Laporan Keuangan}

Menurut Nainggolan (2012:72) "berdasarkan periode penerbitannya, laporan-laporan yang diproduksi oleh yayasan dapat dikategorikan berdasarkan urutan sebagai berikut, yaitu pelaporan setiap bulanan, pelaporan setiap kuartalan, dan pelaporan setiap tahunan."

\section{Pengendalian Keuangan}

Sistem pengendalian keuangan (akuntansi) adalah serangkaian prosedur yang melindungi praktek manajemen secara umum maupun dari segi keuangan. Sistem pengendalian akuntansi diperlukan untuk memastikan pencatatan yang tepat atas barang yang didermakan, sumbangan, dan penerimaan lainnya. Laporan keuangan dan pengembalian informasi harus dicatat secara akurat dan tepat waktu, serta memenuhi peraturan pemerintah lainnya.

\section{Standar Akuntansi Organisasi Nirlaba Berdasarkan PSAK No. 45}

PSAK No. 45 (Revisi 2011) ini efektif diterapkan oleh entitas untuk laporan keuangan periode tahun buku yang dimulai pada atau setelah tanggal 1 Januari 2012. Penerapan dini diperkenankan. Tujuan dibuatnya PSAK No. 45 ini adalah untuk mengatur pelaporan keuangan entitas nirlaba, sehingga dengan adanya pedoman pelaporan diharapkan laporan keuangan entitas nirlaba dapat lebih mudah dipahami, memiliki relevansi, dan memiliki daya banding yang tinggi (IAI, 2011).

\section{Unsur-Unsur Laporan Keuangan Organisasi Nirlaba PSAK No.45}

IAI (2011:45) menetapkan unsur-unsur dalam laporan keuangan organisasi nirlaba berdasarkan PSAK No.45, meliputi:

\section{a. Laporan Posisi Keuangan}

Laporan posisi keuangan merupakan nama lain dari neraca pada laporan keuangan lembaga komersial. Laporan ini memberikan informasi mengenai besarnya aset atau harta lembaga dan sumber perolehan aset tadi (bisa dari hutang atau dari aktiva bersih) pada satu titik tertentu.

\section{b. Laporan aktivitas}

Laporan aktivitas berisi dua bagian besar yaitu besaran pendapatan dan biaya lembaga selama satu periode anggaran. Pendapatan digolongkan berdasarkan restriksi atau ikatan yang ada. Sedangkan beban atau biaya disajikan dalam laporan aktivitas berdasarkan kriteria fungsional, dengan demikian beban biaya akan terdiri dari biaya kelompok program jasa utama dan aktivitas pendukung.

\section{c. Laporan arus kas}

Laporan arus kas menunjukkan arus uang kas masuk dan keluar untuk suatu periode. Periode yang dimaksud adalah periode sama dengan yang digunakan oleh laporan aktivitas.

\section{d. Catatan atas laporan keuangan}

Catatan atas laporan keuangan, merupakan bagian yang tidak terpisah dari laporan-laporan di atas. Tujuan pemberian catatan ini agar seluruh informasi keuangan yang dianggap perlu untuk diketahui pembacanya sudah diungkapkan. 


\section{Tujuan Laporan Keuangan Organisasi Nirlaba PSAK No.45}

PSAK No. 45 memiliki beberapa unsur yang mana tiap unsur tersebut memiliki tujuan-tujuannya tersendiri seperti yang akan dijelaskan berikut ini:

a. Laporan Posisi Keuangan

Tujuan laporan posisi keuangan adalah untuk menyediakan informasi mengenai aktiva, kewajiban, dan aktiva bersih dan informasi mengenai hubungan di antara unsur-unsur tersebut pada waktu tertentu.

b. Tujuan laporan aktivitas

Tujuan utama laporan aktivitas adalah menyediakan informasi mengenai pengaruh transaksi dan peristiwa lain yang mengubah jumlah dan sifat aktiva bersih, hubungan antar transaksi, dan peristiwa lain, dan bagaimana penggunaan sumber daya dalam pelaksanaan berbagai program atau jasa.

c. Laporan arus kas

Tujuan utama laporan arus kas adalah menyajikan informasi mengenai penerimaan dan pengeluaran kas dalam suatu periode.

d. Catatan atas laporan keuangan

Tujuan laporan keuangan termasuk catatan atas laporan keuangan, adalah untuk menyajikan informasi mengenai Jumlah dan sifat aset, liabilitas, dan aset neto entitas nirlaba, dan lainlainnya.

\section{Siklus Akuntansi Organisasi Nirlaba}

Halim (2012) menjelaskan bahwa "siklus akuntansi pada organisasi nirlaba, termasuk organisasi yayasan panti asuhan, dapat dikelompokkan menjadi tiga bagian sebagai berikut, yaitu pencatatan, pengikhtisaran, dan pealporan".

\section{Metode Penelitian \\ Desain Penelitian}

Penelitian ini bertujuan untuk menganalisis kesesuaian penerapan pelaporan keuangan organisasi nirlaba berdasarkan PSAK No. 45 pada Panti Asuhan Yayasan Islam Media Kasih. Jenis penelitian yang diterapkan pada penelitian ini adalah penelitian kualitatif. Situasi studi pada penelitian ini tidak diatur oleh peneliti sehingga berlangsung secara normal dan terjadi di lingkungan yang alami (Sekaran \& Bougie, 2017:115). Tingkat intervensi dalam penelitian ini ialah minimum, dimana peneliti tidak melakukan intervensi dalam mempengaruhi perkembangan dan penerapan pelaporan keuangan pada panti asuhan. Unit analisis dalam penelitian ini adalah organisasi nirlaba, yaitu Panti Asuhan Yayasan Islam Media Kasih. Horizon waktu yang diterapkan pada penelitian ini adalah cross sectional yang berarti pengumpulan data hanya dilakukan sekali saja baik dalam periode harian, mingguan, maupun bulanan untuk dapat menjawab pertanyaan penelitian (Sekaran \& Bougie, 2017:122).

\section{Lokasi Penelitian}

Lokasi penelitian adalah Panti Asuhan Yayasan Islam Media Kasih yang beralamat di Jalan Glee Gurah No. 5 Seutui, Kecamatan Baiturrahman, Kota Banda Aceh, Provinsi Aceh.

\section{Sumber Data}

Data primer yang digunakan peneliti meliputi gambaran umum Panti Asuhan Yayasan Islam Media Kasih dan data perihal penerapan pelaporan keuangan pada Panti Asuhan Yayasan Islam Media Kasih. Adapun data sekunder yang digunakan peneliti yaitu: Sejarah Panti Asuhan Yayasan Islam Media Kasih, Struktur organisasi Panti Asuhan Yayasan Islam Media Kasih, Jumlah anak asuh di Panti Aushan Yayasan Islam Media Kasih, serta laporan keuangan yang tersedia di Panti Asuhan Yayasan Islam Media Kasih, dan lain-lain.

\section{Teknik Pengumpulan Data}

Pada dasarnya pengumpulan data yang dilakukan ialah guna memperoleh informasi yang dapat dipakai untuk menjawab pertanyaan atau masalah yang akan dikaji dalam penelitian. Adapun beberapa teknik yang digunakan dalam pengumpulan data ini adalah observasi, dokumentasi, wawancara, dan studi kepustakaan.

\section{Metode Analisis Data}

Penelitian ini menggunakan metode deskriptif yang bertujuan untuk memberikan gambaran secara sistematis serta hubungan antar fenomena yang diteliti (Nazir, 2013:52). Jenis data yang digunakan ialah data kualitatif, yang menghasilkan data berbentuk deskriptif dan diuraikan dalam bentuk kata kata tertulis atas objek yang diamati (Moleong, 2018:4). 
Adapun tahapan-tahapan analisis data yang dapat dilihat dalam uraian berikut ini:

a. Pada tahap permulaan menganilisis kondisi Panti Asuhan Yayasan Islam Media Kasih secara umum, baik dari struktur maupun kebijakan yang diterapkan dan mengumpulkan data, catatan, dokumen resmi dan dokumentasi yang tersedia dari berbagai sumber informasi terkait dengan perapan pelaporan keuangan pada Panti Asuhan Yayasan Islam Media Kasih. Lalu peneliti mengumpulkan data dari hasil wawancara dengan pihak terkait di Panti Asuhan Yayasan Islam Media Kasih disertai dengan hasil amatan dan catatan laporan yang dilakukan peneliti. Dengan adanya berbagai sumber data itu menunjukkan bahwa terdapat banyak data yang harus ditelaah dengan baik oleh peneliti.

b. Data yang telah dikumpulkan tersebut lalu dibaca, dipelajari, dianalisis, dan ditelaah, terutama laporan keuangannya, agar dapat ditemukan kelemahan dari laporan keuangan yang dibuat oleh pihak panti saat ini.

c. Menganalisis penyaluran, pengkuran, penyajian, dan pengungkapan komponen-komponen akun dalam laporan keuangan.

d. Melaksanakan perancangan konsep rekonstruksi peloran keuangan yang sesuai dengan PSAK No. 45 mengenai pelaporan keuangan organisasi nirlaba setelah dilakukannya analisa dan apabila terdapat kesalahan.

e. Tahapan akhir yaitu menarik kesimpulan dari hasil penelitian yang telah didapatkan sekaligus memberi masukan positif pada Panti Asuhan Yayasan Islam Media Kasih.

\section{Hasil dan Pembahasan}

Pelaporan keuangan organisasi nirlaba di Panti Asuhan Yayasan Islam Media Kasih belumlah sesuai dengan PSAK No. 45. Hal itu terlihat dari penerapan laporan keuangan yang disajikan panti. Pihak Panti Asuhan Yayasan Islam Media Kasih belum menyajikan laporan keuangan sesuai dengan PSAK No. 45 dikarenakan pihak pengurus yang belum mengetahui dan memahami tentang PSAK No. 45, jadi mereka hanya menyusun laporan keuangan berdasarkan pemahaman mereka dan yang telah diajarkan kepada mereka saat pertama kali didirikannya panti asuhan tersebut.

\section{Laporan Posisi Keuangan}

Berisikan informasi tentang aset, liabilitas, dan aset neto. Namun, Panti Asuhan Yayasan Islam Media Kasih masih menyebut laporan posisi keuangan dengan laporan neraca. Laporan neraca ini hanya berisikan penerimaan dan pengeluaran dari panti sendiri. Berdasarkan PSAK No. 45, laporan posisi keuangan maupun catatan atas laporan keuangan sendiri seharusnya menyediakan informasi yang relevan tentang likuiditas, fleksibilitas keuangan, dan hubungan antara aset serta liabilitas.

Tabel 4.1 Penyajian Laporan Posisi Keuangan menurut PSAK No. 45

\begin{tabular}{|l|r|}
\hline \multicolumn{2}{|c|}{$\begin{array}{c}\text { PANTI ASUHAN YAYASAN ISLAM MEDIA KASIH } \\
\text { LAPORAN POSISI KEUANGAN } \\
\text { 31 DESEMBER 2017 }\end{array}$} \\
\hline Aset: & Rp51.859.385 \\
\hline Kas dan Setara Kas & Rp51.859.385 \\
\hline Jumlah Aset & - \\
\hline Kewajiban dan Aset Bersih & Rp17.433.235 \\
\hline Kewajiban & Rp17.433.235 \\
\hline Aset Bersih Tidak Terikat & \\
\hline Jumlah Kewajiban dan Aset & \\
\hline Sumber: Data Olahan 2020
\end{tabular}

1. Aset

Panti Asuhan Yayasan Islam Media Kasih menyebutkan bahwa laporan penerimaan kas panti adalah aset. Hal ini dapat dilihat dari letak jumlah penerimaan yang berada di kolom tempat aset seharusnya berada. Pihak panti belum melakukan penyusutan aset dan juga belum melakukan penyajian valuasi yang jelas terhadap seluruh aset yang dimiliki. Selain itu panti asuhan juga belum melaksanakan penghitungan nilai buku terhadap peralatan dan perlengkapan, hanya data jenis beserta jumlah unit saja yang diberitahukan pada profil panti asuhan.

Pada laporan posisi keuangan berdasarkan PSAK No. 45 disebutkan bahwa segala sesuatu yang menjadi harta bagi panti ini sendiri disebut aset. Pencatatan pada laporannya diurutkan berdasarkan tetap atau tidaknya suatu aset serta lidikuiditas panjang dan pendeknya.

2. Liabilitas dan Aset Neto

Laporan Neraca Keuangan Panti Asuhan Yayasan Islam Media Kasih hanya menyajikan jumlah pengeluaran kas melalui berdasarkan pengelompokannya saja. Tidak terdapat liabilitas pada laporan ini karena seluruh kewajibannya telah dipenuhi sebelum akhir periode. Aset neto dari laporan ini sendiri hanya terdiri dari aset neto tidak terikat karena pihak donatur tidak memberikan pembatasan pada donasinya saat berdonasi, baik donatur tetap maupun tidak tetap. 
Berdasarkan PSAK No. 45, untuk liabilitas atau lebih awam disebut hutang sendiri adalah segala bentuk kewajiban yang belum dilunaskan dan masih wajib dilunaskan oleh pihak panti. Liabilitas ini terbagi menjadi dua, yaitu yang bersifat panjang dan pendek, yang ditentukan berdasarkan umur piutang, apakah dia setahun/satsu periode atau lebih. Bila nantinya terdapat kewajiban yang belum dibayarkan kepada pihak lain, baik itu dikarenakan kurangnya uang untuk menjalankan aktivitas panti, maka wajib untuk dicatat di akun hutang.

Ini sejalan dengan penelitian Gultom yang belum menyajikan laporan keuangan pada objeknya. Selanjutnya hasil penelitian ini juga sejalan dengan hasil penelitian Mamesah dan juga Tinungki yang mana laporan keuangannya hanya terdiri dari kas dan setara kas, tidak memiliki kewajiban apapun karena telah diselesaikan seblum 31 Desember, serta tidak ada nilai buku aset karena penghitungannya belum dilakukan.

\section{Laporan Aktivitas}

Pada laporan ini berisikan informasi mengenai perubahan aset neto tidak terikat, aset neto terikat permanen, dan aset neto terikat temporer. Pendapatan/penghasilan dan keuntungan akan meningkatkan aset neto, sedangkan beban dan kerugian akan mengurangi aset neto. Panti Asuhan Yayasan Islam Media Kasih tidak menyajikan laporan aktivitas, namun segala informasi yang dibutuhkan untuk membuat laporan aktivitas ini telah tersedia dalam Laporan Keuangan Neraca, sehingga dapat dilihat dan disusun berdasarkan informasi tersebut.

Tabel 4.2 Penyajian Laporan Aktivitas Menurut PSAK No. 45

\begin{tabular}{|l|r|}
\hline \multicolumn{2}{|c|}{$\begin{array}{c}\text { PANTI ASUHAN YAYASAN ISLAM MEDIA KASIH } \\
\text { LAPORAN AKTIVITAS } \\
\text { 31 DESEMBER 2017 }\end{array}$} \\
\hline Perubahan Aset Neto Tidak Terikat & \\
\hline Pendapatan: & Rp51.859.385 \\
\hline Sumbangan & Rp51.859.385 \\
\hline Jumlah Pendapatan & Rp5.742.000 \\
\hline Beban: & Rp4.909.000 \\
\hline Biaya Makan & Rp 8.200 .000 \\
\hline Biaya Pendidikan & Rp2.569.000 \\
\hline Gaji Karyawan & Rp12.630.500 \\
\hline Biaya Rumah Tangga & Rp375.000 \\
\hline Biaya Operasional & Rp34.426.150 \\
\hline Biaya Kesehatan & Rp17.433.235 \\
\hline Jumlah Beban & Rp34.426.150 \\
\hline Kenaikan Aset Bersih Tidak Terikat & Rp51.859.385 \\
\hline Aset Bersih Awal Tahun & \\
\hline Aset Bersih Akhir Tahun &
\end{tabular}

1. Pendapatan dan Aset Neto Tidak Terikat

Panti Asuhan Yayasan Islam Media Kasih memang belum memiliki laporan aktivitivas, namun mereka telah mencatat pendapatan panti dalam bentuk laporan penerimaan kas setiap bulannya, baik dari donatur tetap maupun tidak tetap. Dikarenakan sifat donasi dari para donatur tidak diberikan batasan, baik dalam untuk jangka waktu maupun pemanfaatan nilainya, maka pendapatan ini dikategorikan sebagai aset neto tidak terikat. Berdasarkan pedoman pada PSAK No. 45, apabila nantinya panti asuhan mendapatkan suatu donsai yang diberikan pembatasan dalam pemakaian manfaat atau jangka waktu penggunaannya, maka akan dilihat lagi untuk dimasukkan ke bagian mana.

2. Beban

Pihak panti belum memiliki saldo penyusutan karena masih menggunakan pencatatan dengan metode cash basis serta belum membuat revaluasi untuk seluruh asetnya, sehingga informasi penyusutan belum bisa didapatkan. Di samping itu, panti asuhan tidak memiliki pembatasan dalam donasi yang diberikan, sehingga penggunaannya dikategorikan sebagai beban tidak terikat. Berdasarkan PSAK No. 45, sebaiknya dicatat juga beban per program yang dijalankan oleh pihak panti, agar bisa lebih jelas dan mudah dipahmi saat dilihat. Disamping itu, apabila terjadi bencana atau musibah yang tidak diinginkan seperti kebakaran, maka total kerugiannya juga dicatat sebagai beban.

\section{Kenaikan Aset Neto Tidak Terikat}

Maksud dari kenaikan aset neto tidak terikat ini adalah jumlah dari pendapatan tidak terikat yang dikurangi dengan beban tidak terikat yang ada. Seperti yang dijelaskan di atas, panti asuhan hanya memiliki beban tidak terikat. Jadi, aset neto terikat ini dikurangi dengan beban tidak terikat untuk menghasilkan jumlah kenaikan aset neto tidak terikat. Berdasarkan PSAK No. 45, aset neto tidak terikat ini lalu ditambahkan dengan perubahan aset neto terikat temporer dan aset neto terikat permanen yang telah lebih dahulu dicari berapa jumlah masing- masing akun tersebut. Nantinya, hasil dari penjumlahan itu akan menunjukkan apakah panti asuhan mengalami surplus atau defisit pada periode itu.

Berbeda dengan penelitian sebelumnya, laporan aktivitas Panti Asuhan Yayasan Islam Media Kasih tidaklah mendapat pembatasan dalam penggunaannya, namun untuk status aset neto tidak terikatnya adalah sama dengan hasil penelitian Gultom, Tinungki, dan 
Mamesah, dimana penggunaan dana tidak dibatasi untuk keperluan apa saja. Selain itu, sama halnya dengan penelitian Tinungki, sumber dana hanya berasal atau pendapatan hanya berasal dari sumbangan/donasi yang dikumpulkan oleh pihak panti.

\section{Laporan Arus Kas}

Berisikan informasi mengenai penerimaan dan pengeluaran kas dalam suatu periode. Panti Asuhan Yayasan Islam Media Kasih tidak menyediakan laporan arus kas, namun informasi yang dibutuhkan untuk membuat laporan aktivitas sudah tersaji dalam Laporan Keuangan Neraca, walaupun belum lengkap.

Tabel 4.3 Penyajian Laporan Arus Kas Menurut PSAK No. 45

\begin{tabular}{|l|r|}
\hline $\begin{array}{l}\text { PANTI ASUHAN YAYASAN } \\
\text { ISLAM MEDIA KASIH } \\
\text { LAPORAN ARUS KAS } \\
\text { 31 DESEMBER 2017 }\end{array}$ \\
\hline Aktivitas Operasi & \\
\hline Kas dari Donatur & $(\mathrm{Rp} 51.859 .385$ \\
\hline Biaya Makan & $(\mathrm{Rp} 4.909 .000)$ \\
\hline Biaya Pendidikan & $(\mathrm{Rp} 8.200 .000)$ \\
\hline Gaji Karyawan & $(\mathrm{Rp} 2.569 .000)$ \\
\hline Biaya Rumah Tangga & $(\mathrm{Rp} 12.630 .500)$ \\
\hline Biaya Operasional & $(\mathrm{Rp} 375.000)$ \\
\hline Biaya Kesehatan & $\mathbf{R p 1 7 . 4 3 3 . 2 3 5}$ \\
\hline Kas Bersih yang Diterima (Digunakan) Untuk Operasi & Rp17.433.235 \\
\hline Kenaikan Bersih dalam Kas dan Setara Kas & Rp34.426.150 \\
\hline Kas dan Setara Kas pada Awal Tahun & $\mathbf{R p 5 1 . 8 5 9 . 3 8 5}$ \\
\hline Kas dan Setara Kas pada Akhir Tahun & \\
\hline Sumber: Data Olahan 2020 &
\end{tabular}

1. Arus Kas dari Aktivitas Operasi

Panti asuhan Yayasan Islam Media Kasih belum melakukan rekonsiliasi, jadi ada kemungkinan nominal kas yang disajikan dalam laporan neraca keuangan adalah sama dengan jumlah kas yang ada.

Berdasarkan PSAK No. 45, aktivitas operasi dikelompokkan menjadi tiga bagian, yaitu aktivitas operasi, aktivitas investasi, dan aktivitas pendanaan. Kegitanya tentu memiliki tujuan dan isi yang berbeda.

Laporan aktivitas Panti Asuhan Yayasan Islam Media Kasih ini sedikit berbeda dari penelitian sebelumnya dikarenakan lebih sederhana, yaitu hanya ada aktivitas operasi tanpa ada aktivitas pendanaan dan investasi. Seperti halnya penelitian Mamesah, panti asuhan ini sebenarnya memiliki saldo investasi untuk perolehan bangunan asrama putra dan tanah untuk asrama putri, namun belum dilakukan penghitungan nilai bukunya.

\section{Catatan Atas Laporan Keuangan}

Berisikan informasi mengenai jumlah dan sifat dari aset, liabilitas, dan aset neto, serta informasi lainnya. Panti Asuhan Yayasan Islam Media Kasih belum memiliki catatan atas laporan keuangan ini.
Berdasarkan PSAK No. 45, catatan atas laporan keuangan ini juga berisikan keterangan lebih lanjut seperti mengenai program-program yang dimasukkan dalam laporan aktivitas, kebijakan akuntansi yang digunakan, dan informasi lainnya.

Tabel 4.4 Penyajian Catatan Atas Laporan Keuangan Menurut PSAK No. 45

\begin{tabular}{|l|}
\hline \multicolumn{1}{|c|}{$\begin{array}{c}\text { PANTI ASUHAN YAYASAN ISLAM MEDIA KASIH } \\
\text { CATATAN ATAS LAPORAN KEUANGAN } \\
\text { 31 DESEMBER 2017 }\end{array}$} \\
\hline $\begin{array}{l}\text { Catatan A } \\
\text { Panti Asuhan Yayasan Islam Media Kasih menyusun laporan posisi keuangan } \\
\text { berdasarkan laporan penerimaan dan pengeluaran keuangan. Pada setiap akhir } \\
\text { bulan laporan keuangan tersebut akan direkapitulasi berdasarkan kelompoknya } \\
\text { seperti biaya makan, biaya pendidikan, dan lainnya. }\end{array}$ \\
\hline
\end{tabular}

Sumber: Data Olahan 2020

Catatan atas laporan keuangan Panti Asuhan Yayasan Islam Media Kasih merupakan kebijakan dari pihak pengurus. Hal ini sama dengan hasil penelitian Tinungki dan Mamesah.

\section{Kesimpulan, Saran, dan Keterbatasan}

Berdasarkan hasil penelitian dan pembahasan pada bab sebelumnya, maka dapat ditarik kesimpulan sebagai berikut:

a. Panti Asuhan Yayasan Islam Media Kasih belum menerapkan pelaporan keuangan sesuai dengan fotmat laporan keuangan organisasi nirlaba yang terdapat dalam PSAK No. 45. Pihak panti hanya menyajikan laporan sesuai dengan pemahaman mereka dan yang telah diajarkan pada awal masa didirikannya panti asuhan ini.

b. Proses penyusunan laporan keuangan Panti Asuhan Yayasan Islam Media Kasih sudah dapat dipertanggungjawabkan dan transparan. Pihak pengurus selalu memcatat segala penerimaan dan pengeluaran kas untuk yang berhubungan dengan panti setiap harinyanya yang lalu direkapitulasi dalam Laporan Keuangan Neraca yang mereka susun setiap bulannya. Segala aktivitas, program, dan pencapaian dan data penting panti asuhan juga tersimpan dengan baik dan akan ditunjukkan kepada orang-orang yang memiliki kepentingan dengan informasi tersebut.

c. Dikarenakan kurangnya pemahaman pengurus panti asuhan tentang format laporan keuangan organisasi nirlaba, termasuk panti asuhan, dalam PSAK No. 45, maka pihak pengurus menyajikan laporan yang berbeda sesuai pemahaman pengurus. Panti Asuhan Yayasan Islam Media Kasih menyajikan Laporan Posisi Keuangan dengan nama Laporan Posisi Neraca dan menyajikan saldo aset neto pada bagian 
pengeluaran. Lalu panti asuhan belum memiki laporan aktivitas, laporan arus kas, dan catatan atas laporan keuangan sebagaimana harusnya yang tercantum dalam PSAK No. 45, namun sebenarnya pihak panti telah menyajikan informasi-informasi mengenai saldo untuk membuat laporan-laporan tersebut dalam Laporan Keuangan Neraca yang mereka susun.

Berdasarkan dari kesimpulan dan hasil penelitian yang telah diuraikan sebelumnya, maka peneliti memberikan beberapa saran sebagai berikut:

a. Panti Asuhan Yayasan Islam Media Kasih sebaiknya menerapkan format PSAK No. 45 dalam penyajian laporan keuangannya sehingga panti asuhan dapat mempunyai laporan keuangan yang lebih yang lebih baik, berkualitas, berdaya saing tinggi, relevan, akuntabel, dan transparan yang mana akan meningkatkan tingkat kepercayaan publik untuk lebih banyak mendonasikan harta mereka di panti asuhan ini.

b. Panti Asuhan Yayasan Islam Media Kasih sebaiknya melakukan penilaian terhadap aset tidak lancar seperti aset tetap dan perlengkapan yang dimiliki panti agar dapat disajikan juga dalam nilai buku atau harga perolehannya, yang mana nantinya dapat dimasukkan juga dalam laporan keuangan dan tentunya akan semakin meningkatkan kepecrcayaan publik dan rasa tertarik untuk berdonasi di panti ini.

c. Panti Asuhan Yayasan Islam Media Kasih sebaiknya melakukan pelatihan- pelatihan atau edukasi lainnya untuk para pengurus, terutama mengenai pembuatan laporan keuangan yang tentunya telah banyak mengalami perubahan seiring dengan perkembangan zaman agar nantinya dapat menyajikan laporan keuangan panti asuhan yang lebih baik sesuai dengan yang telah ditetapkan oleh standar di Indonesia.

Adapun keterbatasan dalam penelitian ini adalah:

a. Penelitian ini hanya mengambil satu panti asuhan saja sebagai objek.

b. Penelitian ini hanya melihat penerapan PSAK No. 45 dan akuntabilitas serta transpasransi dari panti asuhan.

\section{Daftar Pustaka}

Andarsari, Pipit Rosita. 2016. Laporan Keuangan Organisasi Nirlaba (Lembaga Masjid). Jurnal Ekonomi Universitas Kadiri. Vol. 1 No. 2. Hal. 143-152.

Ardana, Komang. 2012. Perilaku Keorganisasian. Cetakan Pertama. Yogyakarta: Graha Ilmu.

Arikunto, S. 2010. Prosedur Penelitian Suatu Pendekatan Praktik. Jakarta: Rineka Cipta.

Basri, Hasan \& A. K. Siti Nabiha, and M. Shabri Abd. Majid. 2016. Accounting and Accountability in Religious Organizations: An Islamic Contemporary Scholar's Perspective. Gadjah Mada International Journal of Bussines. ISSN 1121-1128 Vol. 18 No. 2. Banda Aceh: Universitas Syiah Kuala.

Bastian, Indra. 2007. Akuntansi Yayasan dan Lembaga Publik. Yogyakarta: Erlangga.

Esterberg, Kristin G., 2002. Qualitative Methods in Social Research. New York: Mc. Graw Hill.

Detikcom. 2019. Pemilik Panti Asuhan Samuel Diduga Pakai Uang Donatur Untuk Perkaya Diri. Melalui (https://news.detik.com/berita/d2506916/pemilik-panti-asuhan-samuel-didugapakai-uang-donatur-untuk- perkaya-diri). Diakses 14 Mei 2019.

Gandaputra, Androe. 2015. Gambaran Self Esteem Remaja yang Tinggal di Panti Asuhan. Jurnal Psikologi Universitas Esa Unggul. Vol. 7 No. 2.

Gultom, I.R. 2015. Analisis Penerapan PSAK No.45 Tentang Laporan Keuangan Organisasi Nirlaba dalam Mencapai Transparansi dan Akuntabilitas Kantor Sinode GMIM. Jurnal EMBA. Vol. 3 No. 4. Hal. 527-537.

Halim, Abdul. 2012. Akuntansi Keuangan Daerah. Edisi Revisi. Jakarta: Salemba Empat.

Harahap, Sofyan Syahri. 2012. Teori Akuntansi Edisi Revisi 2011. Cetakan Keduabelas. Jakarta: PT RajaGrafindo Persada.

Harian Nasional. 2018. Panti Asuhan Perlu Ditinjau Berkala. Melalui (http://www.harnas.co/2018/07/24/panti- 
asuhan-perlu-ditinjau-berkala). Diakses 10 Agustus 2020.

Hendrawan, Rony 2011. Analisis Penerapan PSAK No. 45 Tentang Pelaporan Keuangan Organisasi Nirlaba Pada Rumah Sakit Berstatus Badan Layanan Umum (Studi kasus di RSUD Kota Semarang). Jurnal Universitas Diponegoro. Vol. 2 No. 1.

Hery, Cand. 2013. Teori Akuntansi - Suatu Pengantar. Jakarta: Lembaga Penerbit Fakultas Ekonomi Universitas Indonesia.

Ikatan Akuntan Indonesia. 2011. PSAK No. 45 Revisi 2011. Ikatan Akuntan Indonesia. Jakarta.

Iskandar. 2009. Metodologi Penelitian Kualitatif. Jakarta: Gaung Persada Press. Kementrian Pendidikan dan Kebudayaan Republik Indonesia. 2016. KBBI Daring. Melalui $<$ https://kbbi.kemdikbud.go.id/entri/panti\%20as uhan> [17/ 9/2019).

Kementrian Sosial Republik Indonesia. Keputusan Menteri Sosial RI. Nomor 50/HUK/2004 tentang Standardisasi Panti Sosial dan Pedoman Akreditasi Panti Sosial.

Korompis, Claudia 2014. Penerapan PSAK NO. 45 Tentang Pelaporan Keuangan Organisasi Nirlaba Pada Sanggar Seni Budaya Logos Ma'Kantar. Jurnal Riset Akuntansi Going Concern. Hal. 16-30.

Liadi, Prisca Amelia. 2016. Rekonstruksi Pelaporan Keuangan Organisasi Nirlaba pada Panti Asuhan KAnaan Jember Berdasarkan PSAK Nomor 45 (Revisi 2011). Artikel Ilmiah Mahasiswa 2016: 1-7.

Mamesah, Melisa. 2013. Penerapan PSAK No.45 Pada GMIM Efrata Sentrum Sonder Kaitannya dengan Kualitas Informasi Laporan Keuangan. Jurnal EMBA. Vol. 1 No. 4. Hal. 1717-1728.

Mardiasmo, 2018. Akuntansi Sektor Publik. Yogyakarta: Andi.

Moleong, Lexy J. 2018. Metodologi Penelitian Kualitatif. Bandung: PT. Remadja Rosdakarya.

Nainggolan, Pahala. 2012. Akuntansi Keuangan Yayasan dan Lembaga Nirlaba Sejenis. Jakarta: PT. Raja Grafindo Persada.
Nazir, Moh. 2013. Metode Penelitian. Bogor: Ghalia Indonesia.

Nickels, William G., McHugh, James M., McHugh, Susan M. 2009. Pengantar Bisnis Understanding Business. Buku 1. Edisi Kedelapan. Jakarta: Salemba Empat.

Pontoh, Chenly Ribka S. 2013. Penerapan Laporan Keuangan Organisasi Nirlaba Berdasarkan PSAK No 45 Pada Gereja BZL. Jurnal EMBA ISSN 2303-1174 Vol. 1 No. 3 Juni 2013. Universitas Sam Ratulangi. Manado. Hal. 129139. Diakses: 18 Mei 2019.

Poerwadarminta, W.J.S., 1993. Kamus Umum Bahasa Indonesia. Jakarta: Balai Pustaka.

Purba, Orinton. Panduan Praktis Mendirikan Berbagai Badan Usaha (PT, CV, Firma, Yayasan, Koperasi). Cetakan kesatu. Jakarta: Raih Asa Sukses (Penebar Swadaya Grup).

Reeve, James M., Warren, Carl S., dan Duchac, Jonathan E (terjemahan Damayanti Dian). 2009. Pengantar Akuntansi (Adaptasi Indonesia). Jakarta: Salemba Empat.

Sekaran, Uma \& Bougie, R. 2017. Metode Penelitian Untuk Bisnis Pendekatan PengembanganKeahlian. Jakarta: Salemba Empat.

Sembiring, Seth. 2015. Peran Kerangka Konseptual Akuntansi dalam Pelaporan Keuangan Perusahaan. Jurnal Ekonomi dan Bisnis Universitas Santo Thomas.

Serambinews.com.2019.https://aceh.tribunnews.com/2 014/11/06/polisi-diminta-usut-dugaanpenggelapan-uang-anak-panti. Diakses 14 Mei 2019.

Sugiyono. 2015. Metode Penlitian Kuantitatif Kualitatif $R \& B$. Bandung: Alfabeta.

Tinungki, A.N.M \& Pusung, R.J. 2014. Penerapan Laporan Keuangan Organisasi Nirlaba Berdasarkan PSAK No.45 pada Panti Sosial Tresna Werdha Hana. Jurnal EMBA. Vol. 2 No. 2. Hal. 809-819.

Torang, Syamsir. 2013. Organisasi dan Manajemen (Perilaku, Sturktur, Budaya dan Perubahan Organisasi). Cetakan kesatu. Bandung: Alfabeta. 
TRIBUNnews.com. 2019. Mensos: Saat Ini Ada 41 Juta Anak Terlantar di Indonesia. Melalui (http://www.tribunnews.com/tribunners/2016/02 /03/ mensos-saat-ini-ada-41-juta-anak-terlantardi-indonesia). Diakses 14 Mei 2019.

TRIBUNnews.com. 2019. Polisi Diminta Usut Dugaan Penggelapan Uang Anak Panti. Melalui(http://aceh.tribunnews.com/2014/11/06 /polisi-diminta-usut- dugaan-penggelapanuang-anak-panti). Diakses 14 Mei 2019.

TRIBUNnews.com. 2019. 20 Pengelola Panti Asuhan di Pamekasan Dicurigai Korupsi. Melalui (http://surabaya.tribunnews.com/2009/04/02/20 -pengelola- panti-asuhan-di-pamekasandicurigai-korupsi). Diakses 14 April 2019.

Walter T. Horrison., Charles. T. Hongren. (Dialihbahasakan oleh Gina Gania. 2011). Pengantar Akuntansi. Jakarta: Erlangga.

Yuliarti, Norita Citra. 2014. Studi Penerapan PSAK 45 Yayasan Panti Asuhan Yabappenatim Jember. Jurnal Akuntansi Universitas Jember. Vol. 12 No. 2. Hal. 58-73. 